\title{
6 - 12 Yaş Grubu TÜBİTAK Çocuk Kitaplarının Değerler Eğitimi Yönünden Incelenmesi
}

\author{
Salim Pilav a, Mustafa Orhan ${ }^{\mathrm{b}} \mathrm{c}$
}

\section{Özet}

Bu çalışmanın amacı, TÜBİTAK (Türkiye Bilimsel ve Teknolojik Araştırma Kurumu) tarafından yayımlanan $6-12$ yaş grubunda yer alan kitapların, değerler eğitimi yönünden incelenmesi ve değerler eğitimine katkısını ortaya koymaktır. Bu amaçla TÜBİTAK Çocuk Kitapları arasında 6 - 12 yaş grubunda yer alan 215 çocuk kitabından, 8 - 12 yaş grubuna ait rast gele seçilen hikâye edici (anlatıma dayalı) 11 kitap incelenmiştir. İnceleme sonucunda; En çok sevgi değerine (156 kez), en az da adalet değerine (22 kez) yer verildiği tespit edilmiştir. Araştırmada var olan bir durumu ortaya koymak amaçlandığı için betimsel araştırma yöntemi ve tarama modeli kullanılmıştır. TÜBİTAK tarafından yayımlanan $6-12$ yaş grubunda yer alan 215 kitap bu araştırmanın evrenini oluşturmaktadır. Evren içerisinden, $8-12$ yaş grubuna ait rast gele seçilen hikâye edici (anlatıma dayalı) 11 kitap örneklem olarak alınmıştır. Araştırma, 11 kitapla sınırlandırılmıştır. Elde edilen bulgular ilgili başlıklar çerçevesinde verilmiştir.
Anahtar Kelimeler

TÜBİTAK

Çocuk Edebiyatı

Çocuk Kitapları

Değerler Eğitimi

Makale Hakkında

Geliş Tarihi: 29.06.2020

Kabul Tarihi: 01.09.2020

Doi: 10.18026/cbayarsos.759891

\section{An Investigation of 6 - 12 Age Group TÜBİTAK Children's Books in terms of Values Education}

\section{Abstract}

The purpose of this study is to analyse the books published by TUBITAK (The Scientific and Technological Research Council of Turkey) for the 6-12 age groups in terms of values education and to put forward these books' contribution to values education. In this study, 11 narrative books belonging to the $8-12$ age groups are examined, which are randomly selected among 215 TÜBITAK children's books for the 6 - 12 age groups. This analysis shows that in the books the value of love is referred the most (156 times) while the value of justice is alluded the least (22 times). In this study, descriptive research method and scanning model are used because it is aimed to reveal an existing situation. 215 books in the 6-12 age groups published by TÜBİTAK constitute the population of this research. In this population, randomly selected 11 narrative books belonging to the $8-12$ age groups are chosen samples. The research is limited to 11 books. Findings obtained are given within the framework of related titles.
Keywords

TUBITAK

Children's Literature

Children's Books

Values Education

About Article

Received: 29.06.2020

Accepted: 01.09.2020

Doi: 10.18026/cbayarsos.759891

a Doç. Dr. Kırıkkale Üniversitesi, Eğitim Fakültesi. ORCID: 0000-0001-5141-6282

b Kırıkkale Üniversitesi, Sosyal Bilimler Enstitüsü Doktora Öğrencisi. ORCID: 0000-0002-8559-4834.

c İletişim Yazarı: mustafaorhan1@yahoo.com 


\section{Giriş}

Yaşanılan 21. yüzyıl, teknoloji alanında hızlı gelişmelere sahne olmaktadır. Bu gelişmeler, beraberinde toplumsal gelişmeleri de getirmiştir. Günümüzde insanlar bilgiye hiçbir zaman olmadığı kadar hızlı ulaşabilmekte ve bilgiyi yeteri kadar sorgulamadan, hızlı bir şekilde tüketmektedir. Baş döndürücü bir hızla, hiçbir zaman olmadığı kadar çoklukta elde ettiğimiz bilgilerin yeteri kadar sorgulanmadan, filtre edilmeden tüketilmesi toplumların temel değerlerini olumsuz etkilemektedir. Çocuklar ve gençler, ülke ve insanlık için son derece önemli olan temel değerlerden habersiz bir şekilde yetişmektedir. Ülkelerin geleceğini teşkil eden çocukların ve gençlerin, temel değerlerden habersiz yetişmesi ülke yöneticilerini yeni kararlar almaya yöneltmiş ve pek çok ülke eğitim sistemini gözden geçirmiş, eksiklikleri tespit etmeye çalışmıştır.

Türkiye, toplumunu ayakta tutan milli - manevi ve insani değerlere bağlıllğı ile dünya milletleri arasında örnek gösterilen devletler arasındadır. Buna rağmen, Türkiye'de de değerler kaybının yaşandığı bir gerçektir. Değerler eğitimi ile ilgili çalışmalar gelişmiş ülkelere göre geç de olsa Türkiye' de de başlatılmıştır. Geleceğimizin teminatı olan gençlerin değer eğitiminde en önemli görev alanı itibariyle MEB'e düşmektedir. Değerler eğitimi alanında MEB, son on beş yirmi yıldır büyük bir gayretle çalışmaktadır.

Değerler eğitimini ailede başladığını, okulda pekiştiğini ve toplumda hayat bulduğunu bilmekteyiz. Okullarda okutulan ve konuları itibariyle günlük hayatla iç içe olan dersler aracılığı ile değerlerimizin gelecek nesillere daha kolay aktarılması mümkündür.

Çocuklara ve gençlere değer aktarımını okul ve ders kitaplarıla sınırlı tutmamalı, çocukların ve gençlerin okul dışındaki zamanlarında da değer aktarımına yarayacak materyaller değerlendirilmelidir. Bu anlamda ders dışı kitaplarla da değer aktarımı önemlidir. Velilerin, öğretmenlerin, yazarların ve yayıncıların bu konuda dikkatli olmaları gerekmektedir.

$\mathrm{Bu}$ çalışmada velilere ve öğretmenlere yardımcı olmak amacıyla, bir kamu kurumu olan ve popüler çocuk bilim kitapları alanındaki yayınlarıyla Türkiye'nin önde gelen kurumu olan TÜBITTAK çocuk kitapları aktardıkları değerler açısından incelenmiştir. İlgili literatür incelendiğinde $\mathrm{Bu}$ konuyla ilgili herhangi bir çalışmaya rastlanmamıştır. Alanında bir ilk olduğu için çalışmanın alana önemli bir katkı sağlayacağı düşünülmektedir.

Değerler, Eğitimi, Önemi ve İşlevi

Değer kavramı ile ilgili karşımıza farklı tanımlar çıkmaktadır. Türk Dil “değer” kelimesi için: "Bir şeyin önemini belirlemeye yarayan soyut ölçü, bir şeyin değdiği karşıllk, kıymet. Bir ulusun sahip olduğu sosyal, kültürel, ekonomik ve bilimsel değerlerini kapsayan maddi ve manevi ögelerin bütünü" tanımını yapmaktadır (TDK, 2020). İnsanlar, yaratılışları gereği sosyal varlıklardır ve topluluk halinde yaşamaya programlıdır. Kişinin, içinde yaşadığ toplumda zamana bağlı olarak sürekli bir değişim ve gelişim söz konusudur. Bu değişim ve gelişimle beraber yeni durumlar ortaya çıkmaktadır. İşte kişinin, ortaya çıkan bu değişik durumları anlama ve anlamlandırmada kullandığı temel ölçütlere "değer" denmektedir. Kişi, bu değerleri yaşadığı toplumda ve zaman içinde kazanmaktadır. Yüzyıllar içerisinde yaşanan değişik olayların sonucu ortaya çıkan toplumsal değerlerin, sonraki kuşaklara aktarılması toplumsal kültürün devamlılığı ve millet ruhunun korunması bakımından oldukça önemlidir. 
Değerler eğitimi, doğumdan itibaren ailede başlamakta, okul döneminde okulda, daha sonrasında da sosyal hayatta ve bir ömür boyu devam etmektedir. Değerler eğitiminde, toplumun her bireyine farklı görevler düşmektedir.

Değerler, toplumları meyana getiren temel taşlardır. Bu taşlar yerinden oynatıldığında, toplumun da çözülmeye başlaması kaçınılmazdır. $\mathrm{Bu}$ nedenle toplumbilimciler ve eğitimciler, değerlerin korunmasına ve gelecek nesillere aktarılmasına büyük önem vermektedir.

Yaşadığ1 toplumun değerlerini benimsemeyen kişinin, o toplumda kabul görmesi oldukça zordur. Yine, çalıştığ1 iş yerinde oluşmuş değerlere sahip olmayan kişinin mesleğinden zevk alması, mutlu olması mümkün değildir (Doğan, 2002, s. 144).

İnsan, tutum ve davranışlarını eğitim ile geliştirme özelliğine sahip yaratılmıştır. Yaratılış itibariyle insanın özünde bulunan temel insani vasıflar, kişinin gelişim özelliklerine uygun eğitimle geliştirilebilmektedir. Zamana bağlı olarak insandaki bu temel insani vasıflar eğitim ve çevre şartları ile gelişebilir veya kaybolabilir. Bu nedenle değerler eğitimi büyük önem taşımaktadır.

Değer eğitimi aile başlar. Ailenin, toplumun ve ülkenin temel değerleri ailede öğrenilmekte, bunlarla ilgili eğitim ilk olarak ailede alınmaktadır. Yalan söylememek, paylaşmak, yardım etmek gibi pek çok değer daha küçük yaşlardan itibaren ailede verilmektedir. Temel insani değerlerin ön planda olduğu ailelerde yetişen çocukların değerleri benimsemesi daha kolay olacaktır (Yalçın ve Şengül, 2004). Ailede değer eğitimi verilirken, dikkatli olmak gerekmektedir. Ailede verilen değer eğitimi, okulda verilen değer eğitimi ile zıtlık teşkil ederse, genç kuşaklara değer aktarımı söz konusu olamayacağı gibi, çocuklar da ikilem içinde kalacaklardır (Çelikten, 2019, s. 26).

Geleneksel eğitim anlayışında aileden sonra eğitimde okulun büyük bir önemi vardır. Günümüzde bu anlayıs yavaş yavaş değişmekle birlikte eğitimde okulun halen büyük bir önemi söz konudur Okullar, sadece akademik açıdan başarılı bireyler yetiştirmeyi hedeflemez. Akademik başarının yanında insani değerleri benimsemiş bireyler yetiştirmek de amaçtır. İçinde bulunduğumuz ortam, çocukların aileden sonraki en büyük sosyal çevrelerini oluşturan televizyon ve sanal alemdeki şiddet içirikli programlar, artan zararlı alışkanlıklar, okullarda değerler eğitimimin önemini gözler önüne sermektedir (Kaplan, 2016, s. 800).

Türkiye'de Millı̂ Eğitim Bakanlığı, değer eğitimi konusunda aileden sonra en çok sorumluluk taşıyan kurumdur. Bu nedenle bakanlık, okul öncesi, ilköğretim ve orta öğretim kurumlarında çocuklara verilecek değerleri belirlemiş ve bir program çerçevesinde bu değerlerin eğitiminin verilmesi için çaba sarf etmektedir. Okullarda bu eğitimin verilmesinin “öğrencilerde sağlıklı ve dengeli kişilik oluşturmak, her öğrencinin iyi insan, iyi vatandaş olmasını sağlamak için gerekli bilgi, beceri ve alışkanlıkları kazandırıp onları kendi ahlak anlayışına uygun olarak yetiştirmek" gibi nedenleri vardır (Çelikten, 2019, s. 27).

\section{Değer Eğitiminde Kitap}

Okulda gerçekleştirilen eğitim - öğretim çalışmalarında kitapların ayrı ve önemli bir yeri vardır. Son yıllarda basılı kitapların yerini sanal medya görselleri almaya başlasa da eğitim öğretimde kitabın tartışılmaz üstünlüğünün devam ettiğini söylemek mümkündür. Pek çok 
yetişkin; gerek ders kitaplarından, gerekse ders dışı okuma kitaplarından ilham alarak hayatına yön vermiştir.

Kitaplar herhangi bir konuyla ilgili ansiklopedik bilgi öğrenmek veya genel kültürümüzü arttırmak amaçlı okuduğumuz yardımcı eğitim materyallerinin başında gelmektedir. Ders kitapları da dahil, çocuklar için hazırlanan kitaplarda bulunması gereken bir takım biçim ve içerik özelliklerinin olduğu bilinmektedir. Bu özelliklere dikkat edilmeden hazırlanan kitaplar, çocuklar tarafından sevilerek okunmayacakları için bekledikleri yararı sağlayamayacaklardır.

Çocuklar için hazırlanan kitaplar genel anlamda resimli kitaplardır. Resimli kitaplar, içinde barındırdıkları görsel unsurlar aracılığıyla anlatılanların anlamlandırılmasında aktif rol oynayan, anlatılanların somutlaştırılıp sezinlenmesini sağlayan eserlerdir. Çocuk kitaplarında, okul öncesi yaş gruplarında önemli olan resimdir ve yazı, resmin tamamlayıcı unsuru durumundadır. Çünkü bu dönemde çocuk okuma ve yazmayı bilmemekte, kitap kendisine bir yetişkin tarafından okunmaktadır. Çocuk, kendisine okunan metni, resimlere bakarak zihninde netleştirmektedir. Bu nedenle çocuk kitaplarında seçilen resimler oldukça önemlidir. Çünkü çocuk gördügüüü unutmayacaktır. Gelişim çağındaki bir çocuk kitabında yer alan ve olumsuz duygular çağrıştıran bir resmin, çocuğun zihin dünyasında yapacağ tahribatı tahmin etmek zor değildir.

Çocuklar için ders kitabı dışında anlatıma dayalı veya bilgi verici türde hazırlanan kitaplarda değer eğitimi okul öncesi yaş gruplarında özellikle resimlerle, okul dönemi yaş gruplarına ise hem anlatım hem de resimler yoluyla verilmektedir. Bu nedenle çocuk kitaplarının hem yazı içeriği hem de görsel içeriği oldukça önemlidir. Özellikle yabancı yazarlar tarafından yazılan yazarların kitapları tercih edilecekse hem görsellerine hem de tercümesine özellikle dikkat edilmesi gerekmektedir. Çünkü, başka bir kültürde hazırlanan kitaplarda yer alan görseller, bizim değerlerimize ters olabilmektedir. Bu da değer eğitimi açısından oldukça sakıncalıdır.

Ekonomik kaygılarla yayınlanan pek çok çeviri eserdeki görseller kaynak kültürü ve hedef kültürü bilen çizerler tarafından yeniden düzenlenmek yerine çeviri eserin aslındaki görsellerle piyasa sürülmekte, bu durumun çocuklarda oluşturacağ1 tahribat görmezden gelinmektedir. Oysa hedef kitlesi çocuk olan eserlere daha fazla önem verilmeli konu üzerinde hassasiyetle durulmalıdır. Duygu ve düșünceleri doğru - yanlış süzgecinden geçirmeden olduğu gibi kabul edilmemeli, çocuğun yetişmesinde gereken hassasiyet gösterilmelidir. Çocuklar için hazırlanan çeviri eserlerde eserin metni için gösterilen hassasiyet görseli için de gösterilmelidir (Kaplan, 2016, s. 803).

\section{Türkçe Dersi ve Değerler Eğitimi}

Öğrenciler Türkçe derslerinde güzel konuşmayı, yazıyı güzel yazmayı, duygu ve düşüncelerini en iyi şekilde ifade etmeyi öğrenmektedir. Bunun yanında Türkçe dersleri, öğrencilere toplumsal değerlerin öğretilmesi açısından da önemlidir. Ders işleniş metotları bakımından Türkçe dersleri, diğer derslerden farklıdır. Türkçe dersinde öğrenciler kimi zaman konuşmakta, kimi zaman okumakta, kimi zaman da yazmaktadır. Bütün bu safhalar, genel olarak bir konu etrafında gerçekleşmektedir. Derslerde işlenecek konuların seçiminde değer eğitimine ve iletimine dikkat edilmesi gerekmektedir (Güner, 2019). 
MEB, 2018 yılına kadar Türkçe Dersi Öğretim Programı'nda değerler eğitimine ayrı bir başlık ayırmamıştır. 2018 yılında Türkçe Dersi Öğretim Programı'nda “Değerlerimiz” başlığı altında adalet, dostluk, dürüstlük, öz denetim, sabır, sayg1, sevgi, sorumluluk, vatanseverlik, yardımseverlik adı altında on kök değere yer vermiştir (MEB, 2019). Bu kök değerlere bağlı dostluk, merhamet, eşitlik, paylaşma vb. alt değerler öğrencilere verilmektedir.

Ayrıca, "Yetkinlikler" başlığı altında da, Türkçe Öğretim Programı ile öğrenciye kazandırılması amaçlanan yetkinlikler sıralanmıştır. Toplam sekiz yetkinliğin sıralandığı listede, 6. Sırada yer alan "Sosyal ve vatandaşlıkla ilgili yetkinlikler" ve 8. Sirada yer alan "Kültürel farkındalık ve ifade" başlıkları değer eğitimi ile ilişkilendirilmektedir (Güner, 2019).

İncelenen kitaplar, ders dışı eğitim materyali olarak, anlatım yönüyle Türkçe dersinin kapsam alanında oldukları için, değer eğitimi açısından Türkçe dersi ile aynı kategoride değerlendirilmesi uygun bulunmuştur.

\section{Araştırmanın Amacı}

$\mathrm{Bu}$ araştırmanın amacı, TÜBITTAK tarafından yayımlanan 6 - 12 yaş grubunda yer alan 215 çocuk kitabından, 8 - 12 yaş grubuna ait rast gele seçilen hikâye edici (anlatıma dayalı) 11 kitabın değerler eğitimine katkısını ortaya koymaktır. Bu amaç çerçevesinde aşağıdaki soruya cevap aranacaktır:

1- TÜBİTAK tarafından yayımlanan 6 - 12 yaş grubunda yer alan kitapların değerler eğitimine katkısı nedir?

\section{Yöntem}

Araştırmada var olan bir durumu ortaya koymak amaçlandığ 1 için doküman inceleme yöntemi kullanılmıştır . Nitel araştırma karakteristik özellikleri itibari ile doğal araştırma, yorumlayıcı araştırma ve alan araştırması gibi değişik adlarla ve tanımlarla ifade edilmiştir. Nitel araştırmalarda veri toplamak için yaygın olarak gözlem, görüşme, odak grup görüşmesi ve doküman inceleme yöntemleri kullanılmaktadır. Nitel araştırmada verilerin geçerliliği ve ulaşılan sonuçların doğruluğu önemli olduğu için araştırmacı konusuna ve hedef kitlenin özelliğine göre birden çok araştırma metodundan yararlanabilmektedir (Yıldırım ve Şimşek, 2000).

Nitel Araştırmalarda Çalışma GrubuTÜBİTAK tarafından yayımlanan 6 - 12 yaş grubunda yer alan 215 kitap bu araştırmanın evrenini oluşturmaktadır. Evren içerisinden, 8 - 12 yaş grubuna ait rast gele seçilen hikâye edici (anlatıma dayalı) 11 kitap örneklem olarak alınmıştır. Araştırma, 11 kitapla ve 10 kök değerle sınırlandırılmıştır.

Tablo 1. Araştırmada Kullanılan Kitap Bilgileri

\begin{tabular}{clc}
\hline Sıra & Kitabın Adı & Yaş Grubu \\
\hline 1 & Bay Endişe. & 8 Yaş \\
2 & Elimde Değil. & 8 Yaş \\
3 & Kadim Orman. & 8 Yaş \\
4 & Kalundborg Beşlisi. & 8 Yaş \\
\hline
\end{tabular}




\begin{tabular}{clc}
\hline 5 & Karıncalar Yollarını Kaybeder mi? & 8 Yaş \\
6 & Marie Curie Radyumun İzinde. & 8 Yaş \\
7 & Otizm ve Kardeşim. & 8 Yaş \\
8 & Ölü Balıklar Neden Batmaz? & 8 Yaş \\
9 & Dolaşım Sisteminde Yolculuk. & 9 Yaş \\
10 & Çiko'nun Günlüğ̈ü & 12 Yaş \\
11 & Muciziler Adasına Yolculuk. & 12 Yaş \\
\hline
\end{tabular}

Tablo 1'de, araştırmada incelenen 8 yaş grubuna ait 8,9 yaş grubuna ait 1, 12 yaş grubuna ait 2 kitap olmak üzere toplam 11 kitaba yer verilmiştir.

\section{Verilerin Toplanması ve Analizi}

TÜBİTAK tarafından yayımlanan 6 - 12 yaş grubunda yer alan 215 çocuk kitabından, 8 - 12 yaş grubuna ait rast gele seçilen hikâye edici (anlatıma dayalı) 11 kitapla ilgili elde edilen bulgular ilgili başlıklar çerçevesinde verilmiştir. $\mathrm{Bu}$ çalışmada, elde edilen verilerin değerlendirilmesinde içerik analizi tekniği kullanılmıştır. İçerik analizi yoluyla verileri tanımlama ve verilerin içinde saklı gerçekleri ortaya çıkarmak amaçlanmaktadır. (Gülbahar ve Alper, 2009).

Tablo 2. Değerler Tablosu

\begin{tabular}{ll}
\hline Değer Adı & Değer Türü \\
\hline Adalet & Kök Değer \\
Dostluk & Kök Değer \\
Dürüstlük & Kök Değer \\
Öz Denetim & Kök Değer \\
Sabır & Kök Değer \\
Sayg1 & Kök Değer \\
Sevgi & Kök Değer \\
Sorumluluk & Kök Değer \\
Vatanseverlik & Kök Değer \\
Yardımseverlik & Kök Değer \\
\hline
\end{tabular}

Tablo 2'de, 2018 yılında Türkçe Dersi Öğretim Programı'nda “Değerlerimiz" başlı̆̆ı altında yer alan 10 kök değere yer verilmiştir.

\section{Bulgular}

Bu bölümde TÜBİTAK tarafından yayımlanan 6 - 12 yaş grubunda yer alan 215 çocuk kitabından, 8 - 12 yaş grubuna ait rast gele seçilen hikâye edici (anlatıma dayalı) 11 kitapla ilgili elde edilen bulgular ilgili başlıklar çerçevesinde verilmiştir.

İnceleme sonucunda, 


\section{Adalet}

Adalet sözcüğünün değişik tanımları vardır. Türk Dil Kurumu kavramı "Yasalarla sahip olunan hakların herkes tarafından kullanılmasının sağlanması, türe. Hak ve hukuka uygunluk, hakkı gözetme" olarak tanımlamaktadır (TDK, 2020).Toplum düzeni, adaletin tesisine bağlıdır. Adaletin olmadığı toplumlarda toplumsal huzurdan bahsetmek mümkün değildir.

Tablo 3. Değer Tablosu: Adalet

\begin{tabular}{lllll}
\hline Sıra & Kitabın Adı & Yaş & $f$ & Açıklama \\
\hline $\mathbf{1}$ & Bay Endişe & 8 Yaş & - & Değere hiç yer verilmemiştir. \\
$\mathbf{2}$ & Elimde Değil & 8 Yaş & 1 & Örtük olarak verilmiştir. \\
$\mathbf{3}$ & Kadim Orman & 8 Yaş & 3 & Doğrudan ve örtük olarak verilmiştir. \\
$\mathbf{4}$ & Kalundborg Beşlisi & 8 Yaş & - & Değere hiç yer verilmemiştir. \\
$\mathbf{5}$ & Karıncalar Yollarını Kaybeder mi? & 8 Yaş & - & Değere hiç yer verilmemiştir. \\
$\mathbf{6}$ & Marie Curie Radyumun İzinde & 8 Yaş & 1 & Örtük olarak verilmiştir. \\
$\mathbf{7}$ & Otizm ve Kardeşim & 8 Yaş & - & Değere hiç yer verilmemiştir. \\
$\mathbf{8}$ & Ölü Balıklar Neden Batmaz? & 8 Yaş & - & Değere hiç yer verilmemiştir. \\
$\mathbf{9}$ & Dolaşım Sisteminde Yolculuk & 9 Yaş & - & Değere hiç yer verilmemiştir. \\
$\mathbf{1 0}$ & Çiko'nun Günlüğü & 12 Yaş & 4 & Doğrudan ve örtük olarak verilmiştir. \\
$\mathbf{1 1}$ & Mucizeler Adasına Yolculuk & 12 Yaş & 13 & Doğrudan ve örtük olarak verilmiştir. \\
\hline
\end{tabular}

Tablo 3'teki veriler incelendiğinde; adalet değerine en çok 13 kez "Mucizeler Adasına Yolculuk" kitabında, en az 1'er kez "Elimde Değil" ve "Marie Curie Radyumun İzinde" adlı kitaplarda yer verildiği görülmektedir.

İncelenen beş kitapta doğrudan veya örtük olarak adalet değeri ile ilgili verilmek istenen fikirleri şöyle sıralamak mümkündür: Bir konuda karar vermekte acele etmemek, konuyu etraflıca düşünmek, başkalarına da danışmak gerekmektedir. Aralarında anlaşmazlık bulunan kişiler için hakemlik yapmakta yarar vardır. Adalet, genel olarak resmi görevliler tarafından kanunlar aracılığı ile sağlanmaktadır. Resmi görevliler kanundan kaynaklanan haklarını kötüye kullanarak adaletten sapmamalı, haksızlık yapmamalıdır. Ömrünün bir kısmında başkasına haksızlık yapan birisi, ömrünün kalan kısmında bunun karşılığını genel olarak görmektedir.

İncelenen kitaplarda adalet değeriyle ilgili şu hususlara yer verilmiştir:

-Söylediklerine göre, ağaç kesmek kanun yoluyla yasaklanabilirmiş (Kim, 2017, s. 12). Ağaçların kesilmesi kanun yoluyla yasaklanırsa, adaletin sağlanacağ adalet değerine vurgu yapılmaktadır.

-“Taka,” dedi babam, “Hüküm vermekte acele etme (Gölbaşı, 2019, s. 69). Vereceğimiz kararların adaletli olması için, bir karara varırken aceleci davranmamalıyız. Adalet değerine örtülü vurgu yapılmaktadır. 
-Bir deniz motoru BÜYÜKANNE BREUER'e yaklaştı. Hemen yanlarına demir attıktan sonra, siyah saçlı, üniformalı adamlar BÜYÜKANNE BREUER'in güvertesine geçtiler. Nazik bir biçimde selam verdiler. Pasaportlara ve teknenin evraklarına baktılar. Tekneyi denetledikten sonra ayrıldılar (Kordon, 2011, s. 44). Yazar, resmi görevli kişilerin yaptıkları denetimlerin adaletli olduğunu vurgulamaktadır. Adalet değerine örtülü vurgu yapılmaktadır.

\section{Dostluk}

Türk Dil Kurumu sözlüğünde "Sevilen, güvenilen, yakın arkadaş, gönüldaş, iyi görüşülen kimse. Erkek veya kadının evlilik dışı ilişki kurduğu kimse. Sahibine sevgi gösteren hayvan. Bir şeye aşırı ilgi duyan, koruyan kimse. İyi geçinen, aralarında iyi ilişki bulunan." olaraktanımlanmaktadır (TDK, 2020).

Tablo 4. Değer Tablosu: Dostluk

\begin{tabular}{lllll}
\hline Sıra & Kitabın Adı & Yaş & $f$ & Açıklama \\
\hline $\mathbf{1}$ & Bay Endişe & 8 Yaş & 6 & Doğrudan ve örtük olarak verilmiştir. \\
$\mathbf{2}$ & Elimde Değil & 8 Yaş & 14 & Doğrudan ve örtük olarak verilmiştir. \\
$\mathbf{3}$ & Kadim Orman & 8 Yaş & 18 & Doğrudan ve örtük olarak verilmiştir. \\
$\mathbf{4}$ & Kalundborg Beşlisi & 8 Yaş & 3 & Doğrudan ve örtük olarak verilmiştir. \\
$\mathbf{5}$ & Karıncalar Yollarını Kaybeder mi? & 8 Yaş & 4 & Doğrudan ve örtük olarak verilmiştir. \\
$\mathbf{6}$ & Marie Curie Radyumun İzinde & 8 Yaş & 3 & Doğrudan ve örtük olarak verilmiştir. \\
$\mathbf{7}$ & Otizm ve Kardeşim & 8 Yaş & 21 & Doğrudan ve örtük olarak verilmiştir. \\
$\mathbf{8}$ & Ölü Balıklar Neden Batmaz? & 8 Yaş & 6 & Doğrudan ve örtük olarak verilmiştir. \\
$\mathbf{9}$ & Dolaşım Sisteminde Yolculuk & 9 Yaş & 7 & Doğrudan ve örtük olarak verilmiştir. \\
$\mathbf{1 0}$ & Çiko'nun Günlüğü & 12 Yaş & 34 & Doğrudan ve örtük olarak verilmiştir. \\
$\mathbf{1 1}$ & Mucizeler Adasına Yolculuk & 12 Yaş & 23 & Doğrudan ve örtük olarak verilmiştir. \\
\hline
\end{tabular}

Tablo 4'teki veriler incelendiğinde; dostluk değerine en çok 34 kez "Çiko'nun Günlüğü" kitabında, en az 3'er kez "Kalundborg Beşlisi" ve "Marie Curie Radyumun İzinde" adlı kitaplarda yer verildiği görülmektedir.

İncelenen on bir kitapta doğrudan veya örtük olarak adalet değeri ile ilgili verilmek istenen fikirleri şöyle sıralamak mümkündür. Dostluk, kişisel problemlerin samimi bir şekilde konuşulup paylaşılması, aynı amaç için gönüllü arkadaşların bir araya gelmesidir., Dostluk, beraber gezmek, yemek ve içmektir. Dostluk, günlük yaşamda birbirine karşılık gözetmeksizin yardım etmektir. Dostluk, arkadaşının sürekli iyiliği için uğraşan ve iyiliğini isteyen kişi veya kişiler gibi anlamlarda kullanmışlardır. Kimi zaman da dostluk değerinin karşıtı duygulara yer verilerek, dostluk değeri vurgulanmak istenmiştir.

-Seni seviyorum. (Niner, 2015a, s. 8) Yazar, dosta güzel sözlerle hitap edilmesi, onu sevdiğimizin yüzüne söylenmesi gerektiğini düşünmektedir. Bu sözlerle, dostluk değerine örtülü vurgu yapmaktadır. 
Bir gün okulun kantininde en yakın arkadaşı Mehmet'le oturmuş bir şeyler yiyorlardı (Niner, 2015b, s. 10). Yazar, dostluğun, en yakın arkadaşla beraber bir şeyler yemek olduğunu düşünmektedir. Bu kullanımla, dostluk değerine doğrudan yer vermiştir.

-Biz bazen fiyort sahilinde balık tutar, bazen de uzun kıyı şeridi boyunca köpeklerimizle birlikte koşar, yarışırız. (Nam, 2017, s. 6) Dostluk göstergelerinden biri de dostların iyi günde, kötü günde birlikte olmalarıdır. Yazar, dostluğun bu yönüne dikkat çekmektedir.

Bazen tartışıp kavga ediyoruz ama çoğunlukla iyi anlaşıyoruz (Shapiro, 2015, s. 9). Yazar, dostların zaman zaman tartışsalar da uzun süreli dargın kalmalarını uygun görmemektedir bu nedenle "zaman zaman tartışı kavga ediyoruz ama genellikle iyi anlaşıyoruz" sözüyle bu konuya dikkatimizi çekmektedir.

Candaş, "Benim de annem bugün cevizli mantar yapıp size götürecek." dedi (Gölbaşı, 2019, s. 20). Yazar, yiyecek ikramı ile dostluk değerine vurgu yapılmaktadır.

Silke'nin bir önerisi vardı: "Büyuikanne Breuer! Adını BÜYÜKANNE BREUER koyalım. Bizimle birlikte gelemediğine göre, hiç olmazsa bu şekilde bizimle birlikte olsun." (Kordon, 2011, s. 19) Yazar, kullanılmakta olan eşyalardan birine dostların adını vermekle dostluk değerine örtük bir şekilde vurgu yapmaktadır.

\section{Dürüstlük}

Sözcük olarak dürüstlük, "Sözünde ve davranışlarında doğruluktan ayrılmama.", dürüst ise "Sözünde ve davranışlarında doğruluktan ayrılmayan, doğru; kurallara uygun, yanlışsız." olarak tanımlanmaktadır (TDK, 2020). Dürüstlüğü yalnızca güven duygusu bağlamında düşünmek eksiklik olarak değerlendirilmektedir.

Tablo 5. Değer Tablosu: Dürüstlük

\begin{tabular}{lllll}
\hline Sıra & Kitabın Adı & Yaş & $f$ & Açıklama \\
\hline $\mathbf{1}$ & Bay Endişe & 8 Yaş & 11 & Doğrudan ve örtük olarak verilmiştir. \\
$\mathbf{2}$ & Elimde Değil & 8 Yaş & 25 & Doğrudan ve örtük olarak verilmiştir. \\
$\mathbf{3}$ & Kadim Orman & 8 Yaş & 10 & Doğrudan ve örtük olarak verilmiştir. \\
$\mathbf{4}$ & Kalundborg Beşlisi & 8 Yaş & 2 & Doğrudan ve örtük olarak verilmiştir. \\
$\mathbf{5}$ & Karıncalar Yollarını Kaybeder mi? & 8 Yaş & 1 & Örtük olarak verilmiştir. \\
$\mathbf{6}$ & Marie Curie Radyumun İzinde & 8 Yaş & 3 & Doğrudan ve örtük olarak verilmiştir. \\
$\mathbf{7}$ & Otizm ve Kardeşim & 8 Yaş & 13 & Doğrudan ve örtük olarak verilmiştir. \\
$\mathbf{8}$ & Ölü Balıklar Neden Batmaz? & 8 Yaş & 6 & Doğrudan ve örtük olarak verilmiştir. \\
$\mathbf{9}$ & Dolaşım Sisteminde Yolculuk & 9 Yaş & 10 & Doğrudan ve örtük olarak verilmiştir. \\
$\mathbf{1 0}$ & Çiko'nun Günlüğü & 12 Yaş & 15 & Doğrudan ve örtük olarak verilmiştir. \\
$\mathbf{1 1}$ & Mucizeler Adasına Yolculuk & 12 Yaş & 21 & Doğrudan ve örtük olarak verilmiştir. \\
\hline & & & &
\end{tabular}


Tablo 5'teki veriler incelendiğinde; dürüstlük değerine en çok 25 kez "Elimde Değil" kitabında, en az 1 kez "Karıncalar Yollarını Kaybeder mi? " adlı kitapta yer verildiği görülmektedir.

İncelenen on bir kitapta doğrudan veya örtük olarak dürüstlük değeri ile ilgili verilmek istenen fikirleri şöyle sıralamak mümkündür: Verdiği sözde durmak, sözünün güvenilir olması, yaptığı işleri kurallara uygun ve ahlaklı bir şekilde yapmak. Kendi sağlı̆̆ını ve çevresindekilerin sağlığını ve güvenliğini tehlikeye atmamak, yaptığı bir yanlışı fark edince hatasından dönüp, özür dilemek. Çevresinde gelişen olaylara ve problemlere duyarlı olmak.

-Aslına bakarsan ben de yağmur ormanlarının korunması gerektiğini düşünüyorum (Kim, 2017, s. 14). Yazar, doğaya katkısından dolayı yağmur ormanlarının korunması gerektiği fikrini dürüstlük değeri ile ilişkilendirmektedir.

Beyinleri ve vücutları uykusuzluktan bitap düşse bile ellerindeki zor işi bitirmeye çabalıyorlardı (Birch, 2014, s. 32). Yazar, sorumluluğumuzdaki işlerin bitirilmesi için canla başla çabalamayı dürüstlük olarak değerlendirmekte ve dürüstlük değerine örtülü vurgu yapmaktadir.

"Hayır," dedi, "Seni küçük bir çocuk olarak gördüğüm için değil. Bu, bana ait bir hikâye olmadığı için. Yani Revan teyze ve Şıvga' yı sana ancak Yesari amca anlatabilir, ben değil. Bu mesele böyle." (Gölbaşı, 2019, s. 31). Yazar, başkalarına ait bilginin izinsiz paylaşmanın yanlış olduğunu düşünmekte ve dürüstlük değerine örtük vurgu yapmaktadır.

"Böyle lüks bir tekneye biniyoruz diye, zengin olduğumuzu sandı. İşte bu yüzden bana şantaj yaptı: Ya para verecektik ya da Kostas ve ben tutuklanacaktık!" (Kordon, 2011, s. 111). Yazar, yetkilerin şahsi çıkarlar için kullanılmasını yanlış bulmakta ve dürüstlük değerine örtük olarak vurgu yapmaktadır.

\section{Özdenetim}

Öz denetim, genel anlamda bireyin kendini kontrol altında tutmasıdır. Türk Dil Kurumu, "Daha önemli bir amaca ulaşabilmek için kişinin tepkilerini, davranışlarını veya başka amaca yönelme eğilimini denetleyip kısıtlaması, otokontrol." olarak tanımlamaktadır (TDK, 2020). Öz denetim, daha iyi hedef ve durumlar için kişinin kendi hür iradesi ile yeni birtakım kararlar almasıdır. Öz denetim, kazanılması ve devam ettirilmesi zor olmakla beraber toplumun bütün bireylerinde bulunması gereken bir değerdir. Bu nedenle öz denetim değer eğitimi ailede, çok küçük yaşlardan itibaren verilmelidir.

Tablo 6. Değer Tablosu: Öz Denetim

\begin{tabular}{lllll}
\hline Sıra & Kitabın Adı & Yaş & $f$ & Açıklama \\
\hline $\mathbf{1}$ & Bay Endişe & 8 Yaş & 11 & Doğrudan ve örtük olarak verilmiştir. \\
$\mathbf{2}$ & Elimde Değil & 8 Yaş & 11 & Doğrudan ve örtük olarak verilmiştir. \\
$\mathbf{3}$ & Kadim Orman & 8 Yaş & 4 & Doğrudan ve örtük olarak verilmiştir. \\
$\mathbf{4}$ & Kalundborg Beşlisi & 8 Yaş & - & Değere hiç yer verilmemiştir. \\
$\mathbf{5}$ & Karıncalar Yollarını Kaybeder mi? & 8 Yaş & 3 & Doğrudan ve örtük olarak verilmiştir.
\end{tabular}




\begin{tabular}{lllll}
$\mathbf{6}$ & Marie Curie Radyumun İzinde & 8 Yaş & 5 & Doğrudan ve örtük olarak verilmiştir. \\
$\mathbf{7}$ & Otizm ve Kardeşim & 8 Yaş & 23 & Doğrudan ve örtük olarak verilmiştir. \\
$\mathbf{8}$ & Ölü Balıklar Neden Batmaz? & 8 Yaş & - & Değere hiç yer verilmemiştir. \\
$\mathbf{9}$ & Dolaşım Sisteminde Yolculuk & 9 Yaş & 5 & Doğrudan ve örtük olarak verilmiştir. \\
$\mathbf{1 0}$ & Çiko'nun Günlüğü & 12 & 6 & Doğrudan ve örtük olarak verilmiştir. \\
& & Yaş & & \\
$\mathbf{1 1}$ & Mucizeler Adasına Yolculuk & 12 & \multirow{2}{*}{13} & Doğrudan ve örtük olarak verilmiştir. \\
& & Yaş & &
\end{tabular}

Tablo 6'daki veriler incelendiğinde; öz denetim değerine en çok 23 kez “Otizm ve Kardeşim” kitabında, en az 3 kez "Karıncalar Yollarını Kaybeder mi? " adlı kitapta yer verildiği görülmektedir.

İncelenen dokuz kitapta doğrudan veya örtük olarak öz denetim değeri ile ilgili verilmek istenen fikirleri şöyle siralamak mümkündür: Mevcut durumdan daha iyi bir duruma gelmek için tutum ve davranışları kontrol edip, yanlışlar varsa düzeltmek. Mevcut durumdan daha iyi bir duruma gelmek için gerekiyorsa yeni hareket tarzları belirlemek. Maddi olarak sınırları aşan istekler karşısında arzularımızı kontrol altına almak. Sağlığımız için, yaptıklarımıza ve yediklerimize dikkat edip, ölçüyü kaçırmamak.

Fransa'daki Paris Üniversitesi Marie'nin hayallerinin zirvesiydi. Paris'te de onu farklı bir zorluk bekliyordu, öğretmenlerini anlaması için çok iyi Fransızca öğrenmesi gerekiyordu (Birch, 2014, s. 3). Yazar, hayallerini gerçekleştirmek için Fransızca öğrenmeye değinerek, öz denetim değerini vurgulamıştır.

Kalbine iyi davranmak kalp sorunlarının önlenmesine yardımcı olur. Kalp dostu iki öneri ise doğru beslenmek ve spor yapmaktır (Corcoran, 2015, s. 37). Yazar, yanlış veya eksik bir durum varsa düzeltmek ve buna göre davranmak gerektiğini düşünmekte ve öz denetim değerine vurgu yapmaktadır.

Şu anda içim acıyla dolu evet ama yeniden başlamak için duyduğum cesareti karıma borçluyum,' diyor (Gölbaşı, 2019, s. 105). Yazar, daha iyi sonuçlar için yeni başlangıçlar yapılması gerektiğini savunmakta ve öz denetim değerine vurgu yapmaktadır.

\section{Sabir}

Türk Dil Kurumu, sabır sözcüğünü: “1. Acl, yoksulluk, haksızlık vb. üzücü durumlar karşısında ses çıkarmadan onların geçmesini bekleme erdemi, dayanç. 2. Olacak veya gelecek bir şeyi telaş göstermeden bekleme." olarak tanımlamaktadır (TDK, 2020). Sabır sözcüğünün değişik tanımlarına da rastlanmaktadır. Kavramı "Bireyin kendi iradesi dışında gerçekleşen sıkıntı güç ve zorluklara paniğe kapılmadan, tedirgin olmadan ve şikâyet etmeden soğukkanlılıkla tahammül göstermesi." şeklinde tanımlamanın mümkün olduğu da ifade edilmektedir (Seyyar, 2003, s. 343). Sabır değer eğitimini küçük yaşta alan bireyler, hayatları boyunca karşılaştıkları zorluklarla kolaylıkla başa çıkacaklar ve hayatta daha başarılı olacaklardır. 
Tablo 7. Değer Tablosu: Sabır

\begin{tabular}{lllll}
\hline Sıra & Kitabın Adı & Yaş & $f$ & Açıklama \\
\hline $\mathbf{1}$ & Bay Endişe & 8 Yaş & 3 & Doğrudan ve örtük olarak verilmiştir. \\
$\mathbf{2}$ & Elimde Değil & 8 Yaş & 7 & Doğrudan ve örtük olarak verilmiştir. \\
$\mathbf{3}$ & Kadim Orman & 8 Yaş & - & Değere hiç yer verilmemiştir. \\
$\mathbf{4}$ & Kalundborg Beşlisi & 8 Yaş & 1 & Örtük olarak yer verilmiştir. \\
$\mathbf{5}$ & Karıncalar Yollarını Kaybeder mi? & 8 Yaş & - & Değere hiç yer verilmemiştir. \\
$\mathbf{6}$ & Marie Curie Radyumun İzinde & 8 Yaş & 23 & Doğrudan ve örtük olarak verilmiştir. \\
$\mathbf{7}$ & Otizm ve Kardeşim & 8 Yaş & 6 & Doğrudan ve örtük olarak verilmiştir. \\
$\mathbf{8}$ & Ölü Balıklar Neden Batmaz? & 8 Yaş & - & Değere hiç yer verilmemiştir. \\
$\mathbf{9}$ & Dolaşım Sisteminde Yolculuk & 9 Yaş & - & Değere hiç yer verilmemiştir. \\
$\mathbf{1 0}$ & Çiko'nun Günlüğü & 12 Yaş & 21 & Doğrudan ve örtük olarak verilmiştir. \\
$\mathbf{1 1}$ & Mucizeler Adasına Yolculuk & 12 Yaş & 21 & Doğrudan ve örtük olarak verilmiştir. \\
\hline
\end{tabular}

Tablo 7'deki veriler incelendiğinde; sabır değerine en çok 23 kez "Marie Curie Radyumun İzinde" kitabında, en az 1 kez "Kalundborg Beşlisi" adlı kitapta yer verildiği görülmektedir.

İncelenen yedi kitapta doğrudan veya örtük olarak sabır değeri ile ilgili verilmek istenen fikirleri şöyle sıralamak mümkündür: Kendi iradesi dışında meydana gelen üzücü olaylar karşısında serinkanlı olmak, yapılması gereken bir şeyi söylediği halde yapılmaması karşısında daha fazla dayanma gücünün kalmaması, istenilen veya beklenilen bir sonucun elde edilmesi için zamana ihtiyaç duyulması, istenilen sonucu elde etmek için, yapması gerekenleri israrla yapmaya devam etmek, sevdiğiniz birisinin beklemediğiniz bir davranışı karşısında serinkanlılığ 1 korumak, istenilen hedefe ulaşmak için gerekli iş ve işlemlerin uzun zaman devam etmesi durumunda serinkanlılı̆̆1 korumak.

Marie yıllardır tırmanmayı sürdürdügü dağın zirvesine varmış gibiydi. Her şey o kadar zor olmuştu ki... (Birch, 2014, s. 2). İstediğimiz bir sonucu elde etmek uzun zaman alır ve bu süreç çok zorlu geçebilir. Bu süreçte hedefimizden asla vaz geçmemeli, 1srarla çalışmaya devam etmeliyiz. Yazar, sabır değerine örtük olarak vurgu yapmaktadır.

Güzel bir şeyler yazmak için sabırsızlanıyordum (Gölbaşı, 2019, s. 38). Yazar, sabır değerine vurgu yapmaktadir.

Bay Pitt'in uzun bir süre yoğun bir biçimde çalışması ve ayrıca bir dizi sınava girmesi gerekiyordu (Kordon, 2011, s. 14). Hayatta başarı olmak istiyorsak, çok çalışmalı ve bu dönemde sabırlı olmalıyız. Yazar, sabır değerine örtük vurgu yapmaktadır.

\section{Sayg1}

Türk Dil Kurumu, sayg1 sözcüğünü: “Değeri, üstünlüğü, yaşl1lığı, yararlılığı, kutsallığ1 dolayısıyla bir kimseye, bir şeye karşı dikkatli, özenli, ölçülü davranmaya sebep olan sevgi duygusu, hürmet, ihtiram. Başkalarını rahatsız etmekten çekinme duygusu." olarak tanımlamaktadır (TDK, 2020). 
Tablo 8. Değer Tablosu: Sayg1

\begin{tabular}{lllll}
\hline Sıra & Kitabın Adı & Yaş & $f$ & Açıllama \\
\hline $\mathbf{1}$ & Bay Endişe & 8 Yaş & 6 & Doğrudan ve örtük olarak verilmiştir. \\
$\mathbf{2}$ & Elimde Değil & 8 Yaş & 18 & Doğrudan ve örtük olarak verilmiştir. \\
$\mathbf{3}$ & Kadim Orman & 8 Yaş & 18 & Doğrudan ve örtük olarak verilmiştir. \\
$\mathbf{4}$ & Kalundborg Beşlisi & 8 Yaş & 6 & Doğrudan ve örtük olarak verilmiştir. \\
$\mathbf{5}$ & Karıncalar Yollarını Kaybeder mi? & 8 Yaş & 6 & Doğrudan ve örtük olarak verilmiştir. \\
$\mathbf{6}$ & Marie Curie Radyumun İzinde & 8 Yaş & 3 & Doğrudan ve örtük olarak verilmiştir. \\
$\mathbf{7}$ & Otizm ve Kardeşim & 8 Yaş & 18 & Doğrudan ve örtük olarak verilmiştir. \\
$\mathbf{8}$ & Ölü Balıklar Neden Batmaz? & 8 Yaş & 4 & Doğrudan ve örtük olarak verilmiştir. \\
$\mathbf{9}$ & Dolaşım Sisteminde Yolculuk & 9 Yaş & 5 & Doğrudan ve örtük olarak verilmiştir. \\
$\mathbf{1 0}$ & Çiko'nun Günlüğü & 12 Yaş & 15 & Doğrudan ve örtük olarak verilmiştir. \\
$\mathbf{1 1}$ & Mucizeler Adasına Yolculuk & 12 Yaş & 24 & Doğrudan ve örtük olarak verilmiştir. \\
\hline
\end{tabular}

Tablo 8'deki veriler incelendiğinde; saygı değerine en çok 24 kez "Mucizeler Adasına Yolculuk" kitabında, en az 3 kez "Marie Curie Radyumun İzinde" adlı kitapta yer verildiği görülmektedir.

İncelenen on bir kitapta doğrudan veya örtük olarak saygı değeri ile ilgili verilmek istenen fikirleri şöyle sıralamak mümkündür: Sevdiğimizden dolayı saygı duymak, değerinden dolayı saygı duymak, üstünlüğünden dolayı sayg1 duymak, yaşlılığından dolayı sayg1 duymak, yararlılığından dolayı saygı duymak, kutsallığından dolayı saygı duymak, başkalarını rahatsız etmekten çekinmek, yaptığımız bir hatadan dolayı karşımızdaki kişiden özür dilemek.

Çocuk, yüzü kızararak “Özür dilerim, bilmiyordum," dedi (Niner, 2015b, s. 30). Yazar, sayg1 değerine örtülü vurgu yapmaktadır.

Merhaba Sam Amca, (Kim, 2017, s. 3). Yazar, sayg1 değerine örtülü vurgu yapmaktadır.

Tatillerde annem ve ben Kaliforniya'ya anneannemle dedemi ziyarete gideriz (Shapiro, 2015, s. 18). Yazar, saygı değerini vurgulamaktadır.

Arkadaşın için üzgünüz Melek. Teşekkürler arkadaşlar (Troupe T. K., 2019b, s. 22). Yazar, arkadaşlara saygıdan dolayı ilgileri için teşekkür etmekle, saygı değerine vurgu yapmaktadir.

\section{Sevgi}

Türk Dil Kurumu, sevgi sözcüğünü: “İnsanı bir şeye veya bir kimseye karşı yakın ilgi ve bağlılık göstermeye yönelten duygu." olarak tanımlamaktadır (TDK, 2020). Kamus-1 Türki'de "muhabbet, aşk, şefkat." olarak tanımlanmaktadır (Kamus-1 Türki, 2020). Sevginin diğer adı da muhabbettir. 
Tablo 9. Değer Tablosu: Sevgi

\begin{tabular}{lllll}
\hline Sıra & Kitabın Adı & Yaş & $f$ & Açılama \\
\hline 1 & Bay Endişe & 8 Yaş & 7 & Doğrudan ve örtük olarak verilmiştir. \\
2 & Elimde Değil & 8 Yaş & 5 & Doğrudan ve örtük olarak verilmiştir. \\
3 & Kadim Orman & 8 Yaş & 16 & Doğrudan ve örtük olarak verilmiştir. \\
4 & Kalundborg Beşlisi & 8 Yaş & 9 & Doğrudan ve örtük olarak verilmiştir. \\
5 & Karıncalar Yollarını Kaybeder mi? & 8 Yaş & 3 & Doğrudan ve örtük olarak verilmiştir. \\
6 & Marie Curie Radyumun İzinde & 8 Yaş & 3 & Doğrudan ve örtük olarak verilmiştir. \\
7 & Otizm ve Kardeşim & 8 Yaş & 37 & Doğrudan ve örtük olarak verilmiştir. \\
8 & Ölü Balıklar Neden Batmaz? & 8 Yaş & 5 & Doğrudan ve örtük olarak verilmiştir. \\
9 & Dolaşım Sisteminde Yolculuk & 9 Yaş & 5 & Doğrudan ve örtük olarak verilmiştir. \\
10 & Çiko'nun Günlüğü & 12 Yaş & 33 & Doğrudan ve örtük olarak verilmiştir. \\
11 & Mucizeler Adasına Yolculuk & 12 Yaş & 33 & Doğrudan ve örtük olarak verilmiştir. \\
\hline
\end{tabular}

Tablo 9'daki veriler incelendiğinde; sevgi değerine en çok 37 kez "Otizm ve Kardeşim" kitabında, en az 3'er kez "Karıncalar Yollarını Kaybeder mi? ve Marie Curie Radyumun İzinde" adlı kitaplarda yer verildiği görülmektedir.

İncelenen on bir kitapta doğrudan veya örtük olarak sevgi değeri ile ilgili verilmek istenen fikirleri şöyle sıralamak mümkündür: Bir nesneye veya bir kişiye karşı duyulan yakın ilgi, başkalarını sevme göstergesi. Sevilen kişiler için yapılan fedakârlıklar. Sevilen bireye sevildiğini söyleme, hitap şekli. Sevgi hissedilen bir birey veya canlıya herhangi bir karşılık beklemeden yiyecek veya içecek bir şeyler ikram etmek.

Seni seviyorum (Niner, 2015a, s. 8). Yazar, herhangi bir kişiye veya canlıya karşıya duyduğumuz ilgiyi doğrudan sözcüklerle ifade etmektedir. Sevgi değerine doğrudan vurgu yapilmaktadir.

Lali'yi görünce gerçekten sevindi, gülümser gibi oldu (Gölbaşı, 2019, s. 15). Sevgi duygusu beslediğimizi birisi ile karşılaştı̆̆ımızda mutlu olmamız, sevinmemiz, bu mutluluk ve sevincin yüz hatlarımıza, davranışlarımıza yansıması beklenen bir durumdur. Yazar, sevgi değerine örtük vurgu yapmaktadır.

\section{Sorumluluk}

Türkçe sormak fiilinden türetilen yeni bir kelime olan sorumluluk (Ar. mes'ûliyyet) hukukta "uyulması gereken bir kurala aykırı davranışın hesabını verme, tazminatla yükümlü tutulma, işlenmiş bir suçun gerektirdiği cezayı çekme" anlamına gelmektedir (Yıldız, 2009, s. 380). Türk Dil Kurumu, sorumluluk kavramını "kişinin kendi davranışlarını veya kendi yetki alanına giren herhangi bir olayın sonuçlarını üstlenmesi, sorum, mesuliyet" olarak tanımlamaktadır (TDK, 2020). 
Tablo 10. Değer Tablosu: Sorumluluk

\begin{tabular}{lllll}
\hline Sıra & Kitabın Adı & Yaş & $f$ & Açıklama \\
\hline $\mathbf{1}$ & Bay Endişe & 8 Yaş & 16 & Doğrudan ve örtük olarak verilmiştir. \\
$\mathbf{2}$ & Elimde Değil & 8 Yaş & 12 & Doğrudan ve örtük olarak verilmiştir. \\
$\mathbf{3}$ & Kadim Orman & 8 Yaş & 1 & Örtük olarak verilmiştir. \\
$\mathbf{4}$ & Kalundborg Beşlisi & 8 Yaş & 9 & Doğrudan ve örtük olarak verilmiştir. \\
$\mathbf{5}$ & Karıncalar Yollarını Kaybeder mi? & 8 Yaş & 4 & Doğrudan ve örtük olarak verilmiştir. \\
$\mathbf{6}$ & Marie Curie Radyumun İzinde & 8 Yaş & 7 & Doğrudan ve örtük olarak verilmiştir. \\
$\mathbf{7}$ & Otizm ve Kardeşim & 8 Yaş & 13 & Doğrudan ve örtük olarak verilmiştir. \\
$\mathbf{8}$ & Ölü Balıklar Neden Batmaz? & 8 Yaş & 1 & Örtük olarak verilmiştir. \\
$\mathbf{9}$ & Dolaşım Sisteminde Yolculuk & 9 Yaş & 18 & Doğrudan ve örtük olarak verilmiştir. \\
$\mathbf{1 0}$ & Çiko'nun Günlüğü & 12 Yaş & 12 & Doğrudan ve örtük olarak verilmiştir. \\
$\mathbf{1 1}$ & Mucizeler Adasına Yolculuk & 12 Yaş & 23 & Doğrudan ve örtük olarak verilmiştir. \\
\hline
\end{tabular}

Tablo 10'daki veriler incelendiğinde; sorumluluk değgrine en çok 23 kez "Mucizeler Adasına Yolculuk" kitabında, en az 1'er kez "Kadim Orman" ve “Ölü Balıklar Neden Batmaz" adlı kitaplarda yer verildiği görülmektedir.

İncelenen on bir kitapta doğrudan veya örtük olarak sorumluluk değeri ile ilgili verilmek istenen fikirleri şöyle sıralamak mümkündür: Bireylerin kendilerine karşı vücut sağllğını korumak vb. konulardaki görevleri. Bireylerin ailelerine, aile fertlerine, topluma ve çevrelerine karşı yapmaları gereken çevreyi korumak, toplum sağlığı ve güvenliğini korumak, toplum yararına çalışmalarda bulunmak, çevrenin korunması için çalışmak vb. görevler.

Bir zamanlar ă̆açları kesen insanlar, yağmur ormanının tahrip edilmiş kısımların halkın da desteğiyle tekrar ă̆açlandırmaya çalışıyor (Kim, 2017, s. 28). Yazar, sorumluluk değerine örtük vurgu yapmaktadır.

Paris'te de onu farklı bir zorluk bekliyordu, öğretmenlerini anlaması için çok iyi Fransızca öğrenmesi gerekiyordu (Birch, 2014, s. 3). Yazar, bireyin kendi üzerine düşenleri yerine getirmesi gerektiği düşüncesi ile sorumluluk değerine vurgu yapmaktadır.

Olmazsa okula alışıp kendini rahat hissedene kadar ben de onunla gidip geleceğim (Shapiro, 2015, s. 9). Yazar, sorumluluk değerine vurgu yapmaktadır.

Elimden ne geliyorsa yapmam lazım. Hatta hemen şimdi kalemi bırakıp anne ve babamla konuşacă̆ım (Gölbaşı, 2019, s. 112). Yazar, sorumluluk değerine vurgu yapmaktadır.

\section{Vatanseverlik}

Türk Dil Kurumu vatanseverlik sözcügünü, “doğduğu yeri, evini, köyünü, müstakil devlet sınırları içinde memleketini sevmektir" (TDK, 2020) şeklinde tanımlamaktadır. Vatanseverlik, saldırılara karşı beden gücü ile karşı koymak olarak anlaşılmamalıdır. Doğduğu, büyüdüğü çevreden, ait olduğu ülkeden uzak bir yerde yaşayan bireyin buraları 
özlemesi vatan sevgisinin bir göstergesidir. Vatanseverlik değer eğitimi, çocuklara küçük yaşlardan itibaren verilmelidir. Bu değer eğitimi neticesinde vatanın sevilmesi, gerektiğinde düşmanlara karşı savunulması söz konusu olacaktır.

Tablo 11. Değer Tablosu: Vatanseverlik

\begin{tabular}{lllll}
\hline Sıra & Kitabın Adı & Yaş & $f$ & Açıklama \\
\hline $\mathbf{1}$ & Bay Endişe & 8 Yaş & - & Değere hiç yer verilmemiştir. \\
$\mathbf{2}$ & Elimde Değil & 8 Yaş & - & Değere hiç yer verilmemiştir. \\
$\mathbf{3}$ & Kadim Orman & 8 Yaş & 6 & Doğrudan ve örtük olarak verilmiştir. \\
$\mathbf{4}$ & Kalundborg Beşlisi & 8 Yaş & 11 & Doğrudan ve örtük olarak verilmiştir. \\
$\mathbf{5}$ & Karıncalar Yollarını Kaybeder mi? & 8 Yaş & - & Değere hiç yer verilmemiştir. \\
$\mathbf{6}$ & Marie Curie Radyumun İzinde & 8 Yaş & 3 & Doğrudan ve örtük olarak verilmiştir. \\
$\mathbf{7}$ & Otizm ve Kardeşim & 8 Yaş & 4 & Doğrudan ve örtük olarak verilmiştir. \\
$\mathbf{8}$ & Ölü Balıklar Neden Batmaz? & 8 Yaş & - & Değere hiç yer verilmemiştir. \\
$\mathbf{9}$ & Dolaşım Sisteminde Yolculuk & 9 Yaş & - & Değere hiç yer verilmemiştir. \\
$\mathbf{1 0}$ & Çiko'nun Günlüğü & 12 Yaş & 12 & Doğrudan ve örtük olarak verilmiştir. \\
$\mathbf{1 1}$ & Mucizeler Adasına Yolculuk & 12 Yaş & 23 & Doğrudan ve örtük olarak verilmiştir. \\
\hline
\end{tabular}

Tablo 11'deki veriler incelendiğinde; vatanseverlik değerine en çok 23 kez "Mucizeler Adasına Yolculuk" kitabında, en az 3 kez "Marie Curie Radyumun İzinde" adlı kitaplarda yer verildiği görülmektedir.

İncelenen on bir kitapta doğrudan veya örtük olarak vatanseverlik değeri ile ilgili verilmek istenen fikirleri şöyle sıralamak mümkündür: Bireyin doğduğu, büyüdüğü, yaşadığı yeri evini, odasını sevmesi, oralardan uzakta kalınca oraları özlemesi. Vatanından uzaktayken, vatanı ile ilgili haberlere ilgi duyması. Vatanını her türlü tehlikeden korumak için çalışması. Vatanına karşı olan her türlü sorumluluğunun farkında olması ve bu sorumluluklarını yerine getirmek için çalışması. Vatanına düşmanlık edenlerle dostluk ve arkadaşlık ilişkisinde bulunmaması.

Maddeye ulaşmaya çalışırken ona, Polonya'dan esinlenerek, bir isim bile dü̧̧ü̈mü̧̧lerdi: polonyum (Birch, 2014, s. 22). Yazar, vatanseverlik değerini vurgulamaktadır.

Odama girmesine izin vermiyorum. Odamda benim için değerli olan bir sürü şey var (Shapiro, 2015, s. 21). Yazar, vatanseverlik değerine örtük vurgu yapmaktadır.

Silke sadece başını salladı. Fakat sonra birdenbire öksürüp, ağlamaya başladı ve "Bir daha eve hiç dönmeyecek miyiz?" diye sordu (Kordon, 2011, s. 20). Yazar, vatanseverlik değerine vurgu yapmaktadir.

Anne, başını kamaranın kapısından dışarı uzatıp, teknelerinin önünde bulunan yük gemisini göstererek "Bakın, Alman bandıralı bir gemi!" diye bağırdı. Silke'nin babası da "İnsanın memleketinden bu kadar uzakta bir hemşerisine rastlaması ne güzel bir şey." dedi (Kordon, 2011, s. 77). Yazar, vatanseverlik değerine vurgu yapmaktadır. 


\section{Yardımseverlik}

Türk Dil Kurumu, yardımsever sözcügünün tanımını "Kendi gücünü ve imkânlarını başka birinin iyiliği için kullanma. Bir ülkeye bağış veya ödünç olarak verilen para ve ihtiyaç maddeleri. Bağış, iane. İşlerin daha etkin ve verimli olabilmesi için sağlanan katkı, destek" olarak vermektedir (TDK, 2020). Yardımseverlik, toplumu ayakta tutan önemli bir değerdir. Yardımseverlik eğitimi, küçük yaştan itibaren çocuklara kazandırılması gereken önemli bir eğitimdir.

Tablo 12. Değer Tablosu: Yardımseverlik

\begin{tabular}{lllll}
\hline Sıra & Kitabın Adı & Yaş & $f$ & Açılama \\
\hline $\mathbf{1}$ & Bay Endişe & 8 Yaş & 1 & Örtük olarak verilmiştir. \\
$\mathbf{2}$ & Elimde Değil & 8 Yaş & 1 & Doğrudan verilmiştir. \\
$\mathbf{3}$ & Kadim Orman & 8 Yaş & - & Değere hiç yer verilmemiştir. \\
$\mathbf{4}$ & Kalundborg Beşlisi & 8 Yaş & 3 & Doğrudan ve örtük olarak verilmiştir. \\
$\mathbf{5}$ & Karıncalar Yollarını Kaybeder mi? & 8 Yaş & 1 & Örtük olarak verilmiştir. \\
$\mathbf{6}$ & Marie Curie Radyumun İzinde & 8 Yaş & 1 & Örtük olarak verilmiştir. \\
$\mathbf{7}$ & Otizm ve Kardeşim & 8 Yaş & 11 & Doğrudan ve örtük olarak verilmiştir. \\
$\mathbf{8}$ & Ölü Balıklar Neden Batmaz? & 8 Yaş & 2 & Doğrudan ve örtük olarak verilmiştir. \\
$\mathbf{9}$ & Dolaşım Sisteminde Yolculuk & 9 Yaş & 3 & Doğrudan ve örtük olarak verilmiştir. \\
$\mathbf{1 0}$ & Çiko'nun Günlüğü & 12 Yaş & 12 & Doğrudan ve örtük olarak verilmiştir. \\
$\mathbf{1 1}$ & Mucizeler Adasına Yolculuk & 12 Yaş & 9 & Doğrudan ve örtük olarak verilmiştir. \\
\hline
\end{tabular}

Tablo 12'deki veriler incelendiğinde; yardımseverlik değerine en çok 12 kez "Çiko'nun Günlügü̈" kitabında, en az 1'er kez "Bay Endişe, Elimde Değil, Karıncalar Yollarını Kaybeder mi? ve, Marie Curie Radyumun İzinde" adlı kitaplarda yer verildiği görülmektedir.

İncelenen on bir kitapta doğrudan veya örtük olarak yardımseverlik değeri ile ilgili verilmek istenen fikirleri şöyle sıralamak mümkündür: Bireylere karşılık beklemeden yapılan maddi manevi destek. İşlerin daha iyi yürümesi, istenilen sonucun daha çabuk alınması için çalışmalara katkı sağlamak. Ekonomik, psikolojik ve sağlık problemi yaşayan birisinin problemine çözü aramak.

Salı günleri Dostluk Çemberi adlı bir gruptan iki genç, Ravi ile ilgilenip onunla vakit geçirmek üzere evimize geliyor. Ravi'ye başka çocuklarla oynamayı öğretiyorlar (Shapiro, 2015, s. 7). Yazar, örtük bir şekilde yardımseverlik değerini vurgulamaktadır.

Aramızda olanları biliyormuş. Buna çok ü̈uldü̆̆ü̈ü ve elinden bir şey gelirse yapmak istediğini söyledi. "Olabilir," dedim, "Belki yardımcı olabilirsin bize çünkü Candaş ikimizle de konuşmuyor." (Gölbaşı, 2019, s. 71). Yazar, yardımseverlik değerine vurgu yapmaktadır.

TÜBİTAK Çocuk Kitaplarından araştırmaya konu olan on bir kitabın değerler ile ilgili bulguları Tablo 13'te listelenmiştir: 
Tablo 13. Değer Bulguları

\begin{tabular}{|c|c|c|c|c|c|c|c|c|c|c|c|c|}
\hline Değer/Kitap & 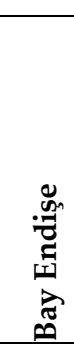 & 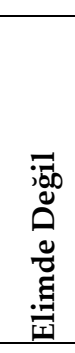 & 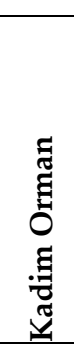 & 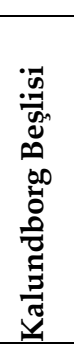 & 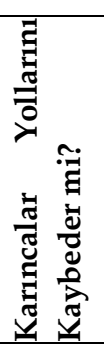 & 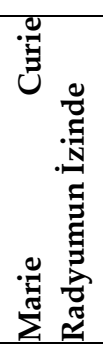 & 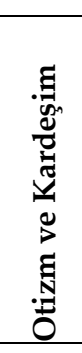 & 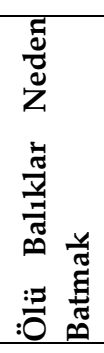 & 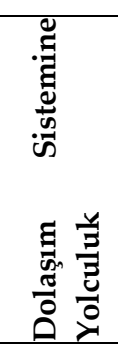 & 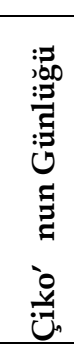 & 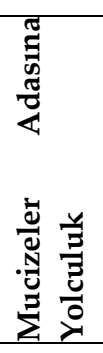 & 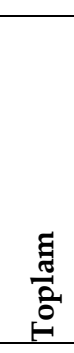 \\
\hline Adalet & 0 & 1 & 3 & 0 & 0 & 1 & 0 & 0 & 0 & 4 & 13 & 22 \\
\hline Dostluk & 6 & 14 & 18 & 3 & 4 & 3 & 21 & 6 & 7 & 33 & 23 & 138 \\
\hline Dürüstlük & 11 & 25 & 10 & 2 & 1 & 3 & 13 & 6 & 11 & 15 & 21 & 118 \\
\hline Öz Denetim & 11 & 11 & 4 & 0 & 3 & 5 & 23 & 0 & 6 & 6 & 12 & 81 \\
\hline Sabir & 3 & 7 & 0 & 1 & 0 & 23 & 6 & 0 & 0 & 23 & 21 & 84 \\
\hline Sayg1 & 6 & 18 & 18 & 6 & 6 & 3 & 24 & 4 & 5 & 15 & 24 & 129 \\
\hline Sevgi & 7 & 5 & 16 & 9 & 3 & 3 & 37 & 5 & 5 & 33 & 33 & 156 \\
\hline Sorumluluk & 16 & 12 & 1 & 9 & 4 & 7 & 13 & 1 & 12 & 18 & 23 & 116 \\
\hline Vatanseverlik & 0 & 0 & 6 & 11 & 0 & 3 & 4 & 0 & 0 & 12 & 9 & 45 \\
\hline Yardımseverlik & 1 & 1 & 0 & 3 & 1 & 1 & 11 & 2 & 3 & 12 & 10 & 45 \\
\hline
\end{tabular}

\section{Sonuç}

Popüler bilim çocuk kitaplarında değerler eğitimini konu alan herhangi bir çalışma yapılmadığı için, bu çalışma alanda ilk olma niteliği taşımaktadır. Bu nedenle de herhangi bir çalışma ile karşılaştırma imkânı bulunamamıştır.

İncelenen 11 kitaptan 10'unun tercüme kitap olması, kitapların tamamının popüler bilim çocuk kitabı olması göz önüne alındığında, değerlere yer verilme oranının azımsanmayacak nitelikte olduğu düşünülmektedir.

Yapılan incelemede, kök değerlerin okuyucuya doğrudan veya örtük bir şekilde verildiği, anlatım ve olayların kesilmediği, doğrudan nasihat edilmediği, doğrudan değer aktarımı sayısının az olduğu tespit edilmiştir.

\section{Öneriler}

Okullarda değer eğitimi en etkili ve kapsamlı bir şekilde Türkçe dersi aracılı̆̆1 ile yapılabilmektedir. Değer eğitiminde istenilen sonuca ulaşmak için sınıf içinde veya sınıf dişında okutulacak kitapların değer eğitimi bakımından gerekli niteliklere sahip olması gerekmektedir. Bu yönüyle, incelenen TÜBİTAK popüler çocuk bilim kitapları çocuklara tavsiye edilebilir.

Çocukların, okulda ve okul dışında okuma alışkanlıklarını arttırmaları için değerler eğitimi bakımından gerekli nitelikte çocuk kitaplarını tespit etmek gerekmektedir. Bu tür kitapların tespiti için, TÜBİTAK popüler çocuk bilim kitaplarının tamamının değerler eğitimi açısından incelenmesi gerekmektedir. 
Popüler çocuk bilim kitabı yazarlığı Türkiye'de emekleme dönemindedir. Yabancı yazarlardan yapılan tercüme kitaplarda da değerler eğitimi istenilen nitelikte olmamaktadır. Kendi yazarlarımıza değerler eğitimi için gerekli niteliklere sahip popüler çocuk bilim kitabı yazmaları için özendirici projeler sunulmalıdır.

Yabancı yazarların popüler çocuk bilim kitaplarının telif hakları alınmadan önce değerler eğitimi yönünden yeterli olup olmadıkları da ayrıca incelenmeli ve yeterli görülmeyen kitapların telif hakları alınmamalı ve bu tür kitaplar yayımlanmamalıdır.

\section{Kaynakça}

Çelikten, F. (2019). Nezihe Meriç'in Çocuk Kitaplarının Değerler Eğitimi Açısından İncelenmesi. Yayımlanmamış Yüksek Lisans Tezi. İstanbul: Marmara Üniversitesi Eğitim Bilimleri Enstitüsü.

Birch, B. (2014). Marie Curie Radyumun İzinde. (N. Baykal, Çev.) Ankara: TÜBİTAK.

Corcoran, M. K. (2015). Dolaşım Sisteminde Yolculuk. (M. Karadağ, Çev.) Ankara: TÜBİTAK.

Demirel, K. (2006). Açıklamalı İnsani Terimler Sözlü̈̆̈̈. İstanbul: Epsilon Yayınları.

Doğan, İ. (2002). Modern Toplumda Vatandaşlık Demokrasi ve İnsan Hakları. Ankara: Pegem Yayıncilı.

Gölbaşı, S. (2019). Çiko'nun Günlüğü. Ankara: TÜBİTAK.

Gülbahar, Y. ve Alper, A. (2009). Öğretim Teknolojileri Alanında Araştırmalar. Ankara Üniversitesi Eğitim Bilimleri Fakültesi Dergisi, 93-111.

Güner, B. (2019). Türkçe Eğitimi Açısından Nurettin Topçu'nun Eserlerinde Değer Eğitimi Unsurları (Yayımlanmamış Yükseklisans Tezi). Kırıkkale: Kırıkkale Üniversitesi Sosyal Bililmler Enstitüsü.

Hökelekli, H. (2008). Adalet. DEM Dergi.

Kamus-ı Türki. (2020, 6 5). https://turki.cagdassozluk.com/osmanlica-sozluk-madde14860.html adresinden alınd 1

Kaplan, K. (2016). Okul Çağındaki Çocuklar İçin Yazılmış Çeviri Eserlerde Kullanılan Görsellerin Değer Aktarımındaki Etkisi. Eğitimde Gelecek Arayışları: Dünden Bugüne Türkiye'de Beceri, Ahlak ve Değerler Eğetimi Uluslararası Sempozyumu (s. 794-810). Ankara: Atatürk Dil ve Tarih Yüksek Kurumu.

Kim, C. (2017). Kadim Orman. (B. Güven, Çev.) Ankara: TÜBİTAK.

Kordon, K. (2011). Mucizeler Adasına Yolculuk. (F. S. Musa Yaşar Sağlam, Çev.) Ankara: TÜBİTAK.

MEB. (2019). Türkçe Dersi Öğretim Programı. Ankara: Milli Eğitim Bakanlığı.

Nam, J. H. (2017). Kalundborg Beşlisi. (B. Güven, Çev.) Ankara: TÜBİTAK.

Niner, H. L. (2015a). Bay Endişe. (M. Ö. Kılıç, Çev.) TÜBİTAK.

Niner, H. L. (2015b). Elimde Değil. (M. Ö. Kılıç, Çev.) Ankara: TÜBİTAK.

Seyyar, A. (2003). Ahlak Terimleri Sözlü̆̆̈̈. İstanbul: Beta Basım AŞ.

Shapiro, O. (2015). Otizm ve Kardeşim. (M. Ö. Kılıç, Çev.) Ankara: TÜBİTAK. 
TDK. (2020, 5 29). Güncel Türkçe Sözlük. Türk Dil Kurumu Web Sitesi: www.sozluk.gov.tr adresinden alınd 1

Troupe, T. K. (2019a). Karıncalar Yolların Kaybeder mi? (N. D. Azak, Çev.) Ankara: TÜBİTAK.

Troupe, T. K. (2019b). Ölü Balıklar Neden Batmaz? (N. D. Azak, Çev.) Ankara: TÜBİTAK.

Yıldırım, A. P., ve Şimşek, H. P. (2000). Sosyal Bilimlerde Nitel Araştırma Yöntemleri. Ankara: Seçkin.

Yıldız, K. (2009). Sorumluluk. Komisyon içinde, İslam Ansiklopedisi (s. 37. Cilt). İstanbul: Türkiye Diyanet Vakfı.

Yalçın, S. K. ve Şengül, M. (2004). Dede Korkut Hikayelerinin Çocuk Eğitimi Açısından Öne Sürdüğü Değerler ve Ortaya Çıkarmak İstediği Tip Üzerine Bir Değerlendirme. Fırat Üniversitesi Sosyal Bilimler Dergisi, 209-223. 